\title{
Outsourcing in Organizational Performance (Case Study: Tehran Water \& Wastewater Supply \& Treatment Co)
}

\author{
S. Derakhshonpour
}

\begin{abstract}
Outsourcing as one of the best practices in Human resources management. Outsourcing tasks include financial savings, increased ability to address strategic planning, access to technology, and the ability to measure and improve service levels. This research, while reviewing the process of outsourcing and its impact on the company's work processes, cost reduction, and enhancement of organizational performance were evaluated. The statistical population of the research is evaluated in order to improve the quality and performance of the outsourcing projects of Tehran Water \& Wastewater Supply \& Treatment Co, and then the managers and senior experts of the company have been formed. The SPSS method was used for this study. A review of cost savings suggests a cost reduction of about $\$ 5.5$ million (around $20 \%$ ) over the five years, as well as outcomes from the company's outsourcing evaluation showed a modest and proper performance, and all outsourcing weaknesses in the company are identified.
\end{abstract}

Index Terms-Outsourcing, organizational performance, human resources.

\section{INTRODUCTION}

Today, topic such as resource constraints, business difficulties, the complexity of technology, increased costs, acceleration of environmental changes, competitive pressures, uncertainty about the future, more specialized work, increasing the size of some organizations, and legal constraints, has led organizations to rethink their management patterns and take new strategies to gain competitive advantage in the current business world. One of these strategies is focusing on core competencies, resulting in the transfer of many activities to outsourced outsourcing resources, in order to provide the possibility of efficient responsiveness, along with customer service and service empowerment. In response to today's diverse demands. Outsourcing in its original sense means that organizations leave part of their activities out of the organization. The term "outsourcing" is used when the company chooses to divide some of its activities and divide it into an external supplier. In other words, outsourcing is a strategic use of external resources to carry out activities traditionally carried out by resources and internal staff of the organization [1].

Their outsourcing and their outsourcing activities are wider every day, and are also welcomed by governments and private companies. This can provide the basis for proper productivity in governments and companies. It should be noted that efficiency is comprised of two components of efficiency and

Manuscript received July 13, 2018; revised September 10, 2018.

S. Derakhshonpour is with the Tehran Water \& Wastewater Supply \& Treatment Co, Iran (e-mail: shderakshan@gmail.com). effectiveness [2], for this purpose, in this study, the effects of outsourcing activity in two parts and cost and performance reduction along with customer satisfaction for the Tehran Water and Wastewater Treatment Company The past five years were monitored from 2012 to 2016, and then the results indicate that the company will increase or decrease its productivity. It should be noted that in this research, the concept of outsourcing will be briefly discussed at a glance of the advantages and challenges of its advancement.

\section{OUTSOURCING}

Outsourcing is the assignment of some recurrent and intermittent domestic activities, as well as the company's decision making authority, to contractors outside it in the form of a contract or memorandum. The concept of this phrase is that not only self-employed activities are delegated, but also the factors of production and decision-making powers associated with it are often assigned. A deliberate and thought-out business decision for the transfer of domestic work to an external supplier. It should be noted that extrapolation is not synonymous with minimization, because by identifying axial competencies, it may be necessary to increase the number of employees at these levels. Outsourcing, in its main form, refers to the purchase of products and services that are already being developed or provided by the company. But this is seen by many companies that outsourcing refers to the purchase of any type of service, regardless of what it has done before. The other definition of outsourcing is as follows: Granting remuneration to provide services to an organization other than the organization itself [3].

\section{OUTSOURCING LOGIC}

Almost all organizations have a growing trend in outsourcing. In a 2004 study by Rison et al., 94\% of the subjects (human resources of organizations) are subordinate to outsourced companies [4]. If an organization needs specialist expertise and cannot hire or train its staff to address this need, then outsourcing that part of the work can be considered an appropriate solution for the organization. Most organizations use outsourcing to save on costs or improve services or access to advanced technology and technology. Outsourcing was used by many managers as an unconfirmed solution, and after a while they find it difficult [5].

The six main reasons for outsourcing organizations are as follows [6]: 1) financial savings, 2) strategic focus, 3) access to advanced technologies, 4) improvement of service levels, 5) Access to specialized specializations, 6) Organizational 
policies.

\section{STRATEGIC FoCUS}

We know that employers do not pursue excellence in all areas. So decide and focus on core capabilities and customer service core (the ultimate goal). The core of each organization is defined according to its basic goals. Outsourcing strategy is a business approach to outsourcing as a widespread organizational initiative and a long-term strategy for achieving sustainable competitive advantage. Researchers outsource outsourcing strategies in terms of the basic goals of each organization's and company's activities [7]. For example, Rashd and Gray divide outsourcing strategies based on two types of environments and centralities based on the importance of what they do in an organization [8]. In contrast, Benny Fazy et al. classified the outsourcing strategies according to the importance of their activities [9]. In this research, the main goals of Tehran water and wastewater Supply and Treatment Company is to reduce the cost and satisfaction of customers, and these two goals are the core of the company, which reduces losses in the company.

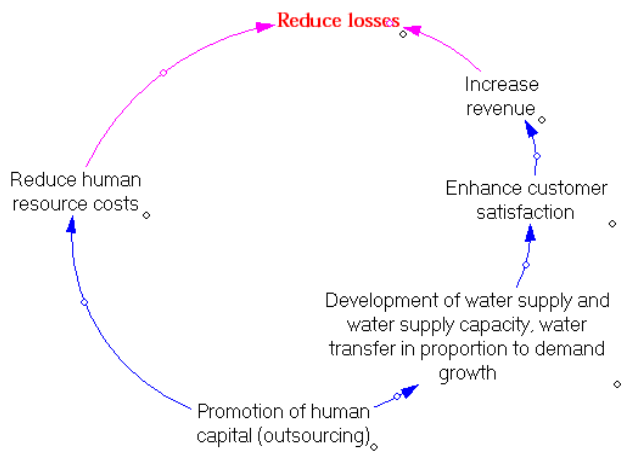

Fig. 1. Strategy in outsourcing of Tehran water \& wastewater supply \& treatment.

\section{ORGANIZATIONAL CONTROL}

An organization, in the process of forming and moving towards the goals set, is constantly faced with various obstacles, each of which, as far as possible, is concerned with channeling the organization to unpredictable paths and sometimes to eliminate it. The acceptance of this fact reveals the need for a control mechanism based on specific and specific standards to ensure and maintain the survival of the organization's objectives [10]. To this end, in this research, the questionnaire design also evaluates the level of control in organizational activities.

From control, various definitions have been made, although they may be different in terms of words, but in terms of meaning and meaning are the same. All these definitions make control a sort of comparison and matching between what is and what it should be. Based on these definitions, the control of the activity is compared to the operations planned with the performed operations, and if there is a difference and a deviation between what should be and what is going to be corrected and corrected [11]. Thus, the control is the activity that compares the inputs with the cores, the desirable ones with the outputs, the predictions with the functions, and gives the manager and the responsible officer a clear picture of the difference or similarity between the two groups of factors. By outsourcing, the amount of control over the organization's management decreases as the functions of the organization are reduced, and if an organization provides its services internally, it can have complete control over the provision of its services [12].

\section{ORgANIZATIONAL PERFORMANCE}

Performance is one of the fundamental concepts in management. Because many of the management tasks are based on it. In other words, success in organizations can be seen in the mirror of their performance. Campbell quotes bassie, who believes that there is a behavior in performance, and that it must be distinguished from results, because some factors can eliminate the results. Organizational performance is to achieve or exceed the organizational and social goals and fulfill the responsibilities assigned to individuals. In general, the factors affecting organizational performance can be summarized as follows: organizational structure organization environment - policies and procedures of the organization. Use the organizational structure to formalize, divide, group, and coordinate tasks. When managers are planning to structure an organization, they should focus on six main factors. These are: division of labor, task grouping, command chain, domain of control, attention to concentration and decentralization, and finally formalization of tasks [14].

\section{FINANCIAL}

TABLE I: RESULTS OF REVIEWING OUTSOURCING CONTRACTS AT TEHRAN WATER AND WASTEWATER SUPPLY \& TREATMENT CO.

\begin{tabular}{|c|c|c|c|}
\hline Year & Description & $\begin{array}{l}\text { Absorb } \\
\text { (person) }\end{array}$ & $\begin{array}{c}\text { Falling out } \\
\text { (person) }\end{array}$ \\
\hline \multirow[t]{2}{*}{2012} & $\begin{array}{l}\text { Personnel contract for } \\
\text { outsourcing }\end{array}$ & 73 & 0 \\
\hline & Formal and regular staff & 30 & 113 \\
\hline \multirow[t]{2}{*}{2013} & $\begin{array}{l}\text { Personnel contract for } \\
\text { outsourcing }\end{array}$ & 73 & 0 \\
\hline & Formal and regular staff & 0 & 64 \\
\hline \multirow[t]{2}{*}{2014} & $\begin{array}{l}\text { Personnel contract for } \\
\text { outsourcing }\end{array}$ & 198 & 0 \\
\hline & Formal and regular staff & 4 & 164 \\
\hline 2015 & $\begin{array}{l}\text { Personnel contract for } \\
\text { outsourcing }\end{array}$ & 0 & 0 \\
\hline \multirow{3}{*}{2016} & Formal and regular staff & 1 & 286 \\
\hline & $\begin{array}{l}\text { Personnel contract for } \\
\text { outsourcing }\end{array}$ & 108 & 0 \\
\hline & Formal and regular staff & 6 & 17 \\
\hline
\end{tabular}

The first reason mentioned for outsourcing decision is saving money. Organizations believe that costs can be reduced by outsourcing, which is a function of wage cuts. Like Krädin, a company that provides software and human resources services in the United States, Canada and Europe. Now more efficient vendors can expand the cost of training personnel and reduce research and development. Outsourcing for two years, the company has shown that there were $10 \%$ to $20 \%$ reduction in costs, and saved an average of $15 \%$ in cost savings [13]. The five-year review of the outsourcing process 
of Tehran's water and wastewater treatment plant has been shown in Table I. The results of the survey showed that the company's current wage and current costs were $\$ 52500000$.

\section{RESEARCH METHODOLOGY}

In another part of this research, the type of research is based on the purpose of applied research type. In the applied research, the researcher achieves results after the various stages of research and testing of the hypotheses that ultimately attempts to provide suggestions for the statistical society of the research in line with the results. Also, considering that this research seeks to investigate the relationship between outsourcing and organizational performance, it is correlated in terms of its nature and method in the research group. In this method, the data were collected through a questionnaire from senior executives and managers of Tehran water and wastewater supply and treatment and sanitation for a 36-member statistical society that has been linked with outsourcing both in the functional sector and in the financial sector.

It is noteworthy that 2000 persons work in the Tehran Water and Wastewater Treatment and Treatment Plant, and their work most important means are to bring healthy water to the 10 million people in Tehran. The supply and refining company has seven centralized treatment plants in Tehran, as well as 72 reservoirs, and the main task is to supply water of the highest quality to the entire city of Tehran. It should be noted that all respondents in this questionnaire had a senior management experience of over 15 years and their qualifications were from baccalaureate to senior.

TABLE II: DESCRIPTION OF SURVEY QUESTIONS

\begin{tabular}{|c|c|c|c|}
\hline Q-N & Question description & Q-N & Question description \\
\hline 1 & How much do you do right? & 9 & How much does standardization work? \\
\hline 2 & $\begin{array}{l}\text { How much does it cost to save on equipment, technology, and } \\
\text { facilities? }\end{array}$ & 10 & $\begin{array}{l}\text { How much does it take to acquire the skills and technology } \\
\text { available outside the organization? }\end{array}$ \\
\hline 3 & How much does the speed of service increase? & 11 & $\begin{array}{l}\text { How much does it retrieve the organizational structure } \\
\text { (redesigning staff for optimal use of their performance)? }\end{array}$ \\
\hline 4 & How do you reduce the cost of organized human resources? & 12 & How to empower human resources? \\
\hline 5 & How much reduced continuous monitoring and control? & 13 & $\begin{array}{l}\text { How much do processes have been engineered (redesigning work } \\
\text { processes to achieve outstanding performance improvements)? }\end{array}$ \\
\hline 6 & How much progress has been made to develop programs? & 14 & How do you reduce the sense of job security among employees? \\
\hline 7 & $\begin{array}{l}\text { How much do you release forces and use them in the main activities? } \\
\text { How much does promotion improve the quality of the product }\end{array}$ & 15 & How much does innovation and creativity increase? \\
\hline 8 & $\begin{array}{c}\text { produced in the beneficiary unit (the unit of work or service } \\
\text { provided)? }\end{array}$ & & \\
\hline
\end{tabular}

TABLE III: KOLMOGOROV-SMIRNOV TEST

\begin{tabular}{ccccc}
\hline \hline Q-N & Mean & $\begin{array}{c}\text { Std. } \\
\text { Deviation }\end{array}$ & k-s & Sig (2-tailed) \\
\hline 1 & 3.44 & 0.84 & 0.245 & 0.000 \\
2 & 3.17 & 1 & 0.214 & 0.000 \\
3 & 3.80 & 0.78 & 0.292 & 0.000 \\
4 & 3.90 & 1 & 0.207 & 0.000 \\
5 & 2.61 & 0.96 & 0.209 & 0.000 \\
6 & 3.11 & 1 & 0.200 & 0.001 \\
7 & 3.11 & 0.97 & 0.235 & 0.000 \\
8 & 3.25 & .84 & 0.230 & 0.000 \\
9 & 2.94 & 0.86 & 0.304 & 0.000 \\
10 & 2.61 & 0.90 & 0.222 & 0.000 \\
11 & 3.14 & 0.93 & 0.239 & 0.001 \\
12 & 2.80 & 1 & 0.202 & 0.000 \\
13 & 2.86 & 0.79 & 0.291 & 0.000 \\
14 & 3.1 & 1.1 & .0277 & 0.000 \\
15 & 2.45 & 0.87 & 0.277 & 0.000 \\
\hline \hline
\end{tabular}

In order to analyze the data obtained from the questionnaire the Kolmogorov-Smirnov method, correlation coefficient, by using SPSS software is used. The questions set in the questionnaire are based on the most important role of outsourcing in the supply and treatment of Tehran's water and sewage, the explanation of the questions examined in this section in Table II and the results of the analysis of data analysis from the survey in Table III given.

Considering that the significance level of data distribution for all variables is less than 0.05 less than the Spearman's rho correlation distribution for research hypotheses.

\section{ANALYSIS}

In sum, the outsourcing of the Tehran Water and Wastewater Supply \&Treatment Company was positive and with a high average performance, and achieved a successful success in reducing human costs, reducing annual costs of about $20 \%$ of their human resources. Is. Also, the results obtained from a detailed review of outsourcing activities in organizational performance (as seen in Table IV) yielded the following results:

1. In response to the correct accomplishment of tasks by outsourcing activities, the results indicate satisfactory and direct relevance of this factor in acquiring the necessary skills and technologies.

2. The impact of outsourcing on reducing costs and saving on the cost of medium-pricing equipment and the direct relevance to human resource empowerment.

3. Increasing the speed of outsourcing services Some of the activities in the good company are evaluated and there is a direct relationship with the correct accomplishment of the tasks and that the activities of the outsourcing company in the supply and refining company of Tehran in the service speed section and in the correct section of the work are positive.

4. The impact of outsourcing on the reduction of staffing costs of the company is high, and to a certain extent, there is a direct connection to the empowerment of forces and the 
process of engineering.

5. The impact of outsourcing on reducing control and continuous monitoring is low, and there is a direct correlation between reducing control and standardizing the work processes, as well as by empowering forces and engineering.

6. The impact of outsourcing on the development and development of programs is moderate and with the acquisition of skills and staffing for direct use direct contact.

7. Outsourcing in the liberation of forces and their use in the main activity of the average assessment. It also partly contributes directly to product quality.

TABLE IV: SPEARMAN CORRELATION TABLE ANSWERING QUESTIONS

\begin{tabular}{|c|c|c|c|c|c|c|c|c|c|c|c|c|c|c|c|c|}
\hline Q-N & & 1 & 2 & 3 & 4 & 5 & 6 & 7 & 8 & 9 & 10 & 11 & 12 & 13 & 14 & 15 \\
\hline \multirow[t]{2}{*}{1} & $\begin{array}{c}\text { Correlation } \\
\text { coefficient }\end{array}$ & 1 & 0.32 & 0.51 & 0.17 & 0.39 & 0.57 & 0.09 & 0.49 & 0.61 & 0.55 & 0.6 & 0.48 & 0.36 & 0.03 & 0.18 \\
\hline & $\operatorname{Sig}(2$-tailed) & .. & 0.05 & 0.001 & 0.31 & 0.02 & 0.0 & 0.59 & 0.002 & 0.0 & 0.0 & 0.0 & 0.0 & 0.03 & 0.85 & 0.3 \\
\hline \multirow[t]{2}{*}{2} & $\begin{array}{l}\text { Correlation } \\
\text { coefficient }\end{array}$ & 0.32 & 1 & 0.3 & 0.38 & 0.1 & 0.06 & 0.22 & 0.003 & 0.2 & 0.26 & 0.29 & 0.26 & 0.53 & 0.13 & 0.14 \\
\hline & Sig(2-tailed) & 0.05 & .. & 0.07 & 0.02 & 0.5 & 0.7 & 0.2 & 0.98 & 0.25 & 0.88 & 0.08 & 0.13 & 0.0 & 0.45 & 0.42 \\
\hline \multirow[t]{2}{*}{3} & $\begin{array}{l}\text { Correlation } \\
\text { coefficient }\end{array}$ & 0.52 & 0.3 & 1 & 0.08 & 0.42 & 0.41 & 0.39 & 0.4 & 0.39 & 0.38 & 0.23 & 0.36 & 0.39 & 0.45 & 0.21 \\
\hline & Sig(2-tailed) & 0.0 & 0.07 & .. & 0.6 & 0.01 & 0.01 & 0.01 & 0.01 & 0.01 & 0.02 & 0.16 & 0.03 & 0.01 & 0.79 & 0.9 \\
\hline \multirow[t]{2}{*}{4} & $\begin{array}{l}\text { Correlation } \\
\text { coefficient }\end{array}$ & 0.17 & 0.38 & 0.08 & 1 & 0.04 & 0.04 & 0.33 & 0.03 & 0.02 & 0.13 & 0.35 & 0.35 & 0.35 & 0.01 & 0.18 \\
\hline & $\operatorname{Sig}(2$-tailed) & 0.31 & 0.02 & 0.6 & .. & 0.8 & 0.8 & 0.05 & 0.84 & 0.9 & 0.42 & 0.03 & 0.03 & 0.03 & 0.9 & 0.29 \\
\hline \multirow[t]{2}{*}{5} & $\begin{array}{l}\text { Correlation } \\
\text { coefficient }\end{array}$ & 0.4 & 0.1 & 0.41 & 0.04 & 1 & 0.26 & 0.17 & 0.22 & 0.22 & 0.52 & 0.46 & 0.5 & 0.41 & 0.12 & 0.15 \\
\hline & Sig(2-tailed) & 0.01 & 0.5 & 0.01 & 0.8 & .. & 0.12 & 0.32 & 0.18 & 0.2 & 0.0 & 0.0 & 0.0 & 0.01 & 0.46 & 0.36 \\
\hline \multirow[t]{2}{*}{6} & $\begin{array}{l}\text { Correlation } \\
\text { coefficient }\end{array}$ & 0.57 & 0.06 & 0.41 & 0.04 & 0.26 & 1 & 0.32 & 0.48 & 0.49 & 0.48 & 0.48 & 0.37 & 0.12 & 0.1 & 0.02 \\
\hline & Sig(2-tailed) & 0.0 & 0.7 & 0.01 & 0.8 & 0.12 & .. & 0.05 & 0.0 & 0.0 & 0.0 & 0.0 & 0.02 & 0.47 & 0.54 & 0.9 \\
\hline \multirow{2}{*}{7} & $\begin{array}{l}\text { Correlation } \\
\text { coefficient }\end{array}$ & 0.09 & 0.22 & 0.39 & 0.32 & 0.17 & 0.32 & 1 & 0.38 & 0.2 & 0.2 & 0.35 & 0.25 & 0.3 & 0.07 & 0.3 \\
\hline & Sig(2-tailed) & 0.6 & 0.2 & 0.01 & 0.05 & 0.32 & 0.05 & .. & 0.02 & 0.26 & 0.25 & 0.03 & 0.13 & 0.07 & 0.6 & 0.06 \\
\hline \multirow[t]{2}{*}{8} & $\begin{array}{l}\text { Correlation } \\
\text { coefficient }\end{array}$ & 0.49 & 0.0 & 0.4 & 0.03 & 0.22 & 0.47 & 0.38 & 1 & 0.46 & 0.24 & 0.36 & 0.27 & 0.19 & 0.01 & 0.26 \\
\hline & Sig(2-tailed) & 0.0 & 0.98 & 0.01 & 0.8 & 0.19 & 0.0 & 0.02 & .. & 0.0 & 0.14 & 0.02 & 0.1 & 0.24 & 0.9 & 0.12 \\
\hline \multirow[t]{2}{*}{9} & $\begin{array}{l}\text { Correlation } \\
\text { coefficient }\end{array}$ & 0.61 & 0.19 & 0.39 & 0.02 & 0.22 & 0.48 & 0.19 & 0.46 & 1 & 0.62 & 0.38 & 0.52 & 0.56 & 0.1 & 0.3 \\
\hline & $\operatorname{Sig}(2$-tailed) & 0.0 & 0.25 & 0.01 & 0.9 & 0.2 & 0.0 & 0.26 & 0.0 & .. & 0.0 & 0.02 & 0.0 & 0.0 & 0.3 & 0.08 \\
\hline \multirow[t]{2}{*}{10} & $\begin{array}{l}\text { Correlation } \\
\text { coefficient }\end{array}$ & 0.55 & 0.02 & 0.38 & 0.13 & 0.51 & 0.49 & 0.19 & 0.24 & 0.63 & 1 & 0.53 & 0.64 & 0.50 & 0.08 & 0.3 \\
\hline & Sig(2-tailed) & 0.0 & 0.9 & 0.02 & 0.42 & 0.0 & 0.0 & 0.25 & 0.14 & 0.0 & .. & 0.0 & 0.0 & 0.0 & 0.6 & 0.07 \\
\hline \multirow[t]{2}{*}{11} & $\begin{array}{l}\text { Correlation } \\
\text { coefficient }\end{array}$ & 0.59 & 0.3 & 0.23 & 0.35 & 0.45 & 0.48 & 0.35 & 0.36 & 0.38 & 0.53 & 1 & 0.76 & 0.41 & 0.1 & 0.35 \\
\hline & Sig(2-tailed) & 0.0 & 0.08 & 0.17 & 0.03 & 0.0 & 0.0 & 0.03 & 0.02 & 0.02 & 0.0 & .. & 0.0 & 0.01 & 0.2 & 0.03 \\
\hline \multirow{2}{*}{12} & $\begin{array}{l}\text { Correlation } \\
\text { coefficient }\end{array}$ & 0.49 & 0.26 & 0.36 & 0.36 & 0.5 & 0.37 & 0.25 & 0.27 & 0.52 & 0.65 & 0.76 & 1 & 0.52 & 0.12 & 0.43 \\
\hline & $\operatorname{Sig}(2$-tailed) & 0.0 & 0.12 & 0.3 & 0.03 & 0.0 & 0.02 & 0.13 & 0.1 & 0.0 & 0.0 & 0.0 & .. & 0.0 & 0.47 & 0.0 \\
\hline \multirow[t]{2}{*}{13} & $\begin{array}{l}\text { Correlation } \\
\text { coefficient }\end{array}$ & 0.36 & 0.53 & 0.39 & 0.35 & 0.41 & 0.12 & 0.3 & 0.2 & 0.56 & 0.5 & 0.41 & 0.52 & 1 & 0.15 & 0.2 \\
\hline & $\operatorname{Sig}(2$-tailed) & 0.02 & 0.0 & 0.17 & 0.03 & 0.01 & 0.47 & 0.07 & 0.24 & 0.0 & 0.0 & 0.01 & 0.0 & .. & 0.3 & 0.18 \\
\hline \multirow[t]{2}{*}{14} & $\begin{array}{l}\text { Correlation } \\
\text { coefficient }\end{array}$ & 0.03 & 0.12 & 0.04 & 0.01 & 0.1 & 0.1 & 0.07 & 0.01 & 0.17 & 0.08 & 0.18 & 0.12 & 0.15 & 1 & 0.0 \\
\hline & Sig(2-tailed) & 0.8 & 0.45 & 0.8 & 0.9 & 0.46 & 0.54 & 0.67 & 0.9 & 0.31 & 0.6 & 0.27 & 0.47 & 0.37 & .. & 0.9 \\
\hline \multirow{2}{*}{15} & $\begin{array}{l}\text { Correlation } \\
\text { coefficient }\end{array}$ & 0.17 & 0.14 & 0.02 & 0.18 & 0.15 & 0.02 & 0.3 & 0.26 & 0.29 & 0.3 & 0.34 & 0.43 & 0.22 & 0.0 & 1 \\
\hline & Sig(2-tailed) & 0.3 & 0.42 & 0.9 & 0.3 & 0.36 & 0.9 & 0.06 & 0.12 & 0.08 & 0.07 & 0.04 & 0.0 & 0.18 & 0.9 & .. \\
\hline
\end{tabular}

8. Outsourcing to improve the quality of the product's average evaluation. There is also a direct relationship with the correct accomplishment of tasks and the development and development of programs.

9. Outsourcing in the standardization of mid-work processes and direct relationship with engineering work and human resource capabilities.

10. Achieving skills and technologies with outsourced activities is low and, as we have said, is directly related to skills and technologies.

11. Outsourcing to staffing for more efficient use of mediation, and a straightforward connection with doing things right.

12. Human resource empowerment with outsourcing activities is moderate.
13. Process engineering in outsourcing activities is moderate and directly linked to the standardization of work processes.

14. With outsourcing activities, a high level of job security is highly evaluated.

15. Outsourcing in the innovation and creativity of employees and average assessment is directly related to human resource capabilities.

\section{CONCLUSION}

The results show that outsourcing in the performance of the Tehran Water and Wastewater Supply \& Treatment Company is moderate and is very suitable for the reduction of manpower costs. But in this research, all aspects of 
outsourcing have been investigated and in some cases, outsourcing has not been successful and the purpose of this study was to check outsourcing in all aspects of the supply and refinement company.

In the third millennium, using managerial principles and the use of economic management in organizations, we must look for appropriate solutions in organizational terms that will lead to upstream constraints, to make decisions based on existing constraints. It seems that prioritizing the activities of the organization to the private sector should pay more attention to three topic of organizational structure, comprehensive service description, control and supervision.

In the Tehran Water and Wastewater Supply and Treatment Company, the division is divided into two parts: non-outsourced and outsourced. In this model, the supervisory and control baccalaureate units that are directly linked to the organization are usually centrally managed through the official personnel of the administration and operational sectors through outsourcing to the private sector. With the comprehensive definition of work and processes, the Overseen Branch has implemented ongoing and expanded operations. The non-outsourced part of the task is to develop and implement the company's strategies and monitor and control the momentum of the required inspections.

Naturally, there is no use of people specializing in the outsourcing sector that has technical, operational, and management thinking. The proper definition and comprehensive description of the services allowed for the part of outsourcing activities to be based precisely on the description of the services and the establishment of the penal system if the proper implementation of the tasks extracted from the precise monitoring of the non-existent sector was not possible and Resulting in a reduction in the cost of execution at a desirable and significant level, and ultimately reducing the cost of completion.

\section{REFERENCES}

[1] P. S. Adler, "Making the HR outsourcing decision," MIT Sloan Management Review, vol. 45, no. 1, pp. 53-60, 2003.

[2] D. Albertson, "Outsourcing shows limited impact for strategic HR," Employee Benefit News, vol. 14, no. 10, pp. 70, 2000.

[3] M. Alexander and D. Young, "Strategic outsourcing," Long Range Planning, vol. 29, no. 1, pp. 116-119, 1996.

[4] P. Babcock, "Slicing off pieces of HR," HR Magazine, vol. 49, no. 7, pp. 70-76, 2004.

[5] J. Sullivan, "The case against outsourcing," Canadian HR Reporter, vol. 17, no. 3, p. 15, 2004.

[6] D. J. Bryce and M. Useem, "The impact of corporate outsourcing on company value," European Management Journal, vol. 16, no. 6, pp. 635-643, 1998.

[7] D. Burn, "Outsourcing: Transforming the role of human resource professionals," HR Professional, pp. 26-33, 1997, February/March.

[8] D. Burn, "To outsource training or not to outsource training: That is the question," Human Resources Professional, vol. 15, no. 1, 1998, February/March.

[9] B. Cooke, "HR/benefits outsourcing: Updating the conventional thinking," Employee Benefit Plan Review, vol. 58, no. 8, pp. 18-22, 2004.

[10] D. Elmuti and Y. Kathawala, "The effects of global outsourcing strategies on participants' attitudes and organizational effectiveness," 2000.

[11] J. D. Lilly, D. A. Gray, and M. Virick, "Outsourcing the human resources function: Environmental and organizational characteristics that affect," 2005.

[12] HR performance, Journal of Business Strategies, vol. 22, no. 1, pp. 55-74.

[13] A. McCauley, "Know the benefits and costs of outsourcing services," Canadian HR Reporter, vol. 13, no. 17, pp. 18-19, 2000, October 9.

[14] M. Oshima, T. Kao, and J. Tower, "Achieving post-outsourcing success," Human Resources Planning, vol. 28, no. 2, pp. 7-12, 2005.

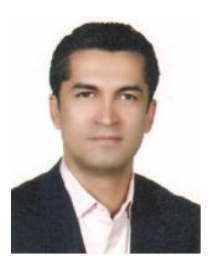

S. Derakhshanpour lives in Iran and he was born in 1970 in Tehran.

He holds a master's degree in executive management from the Islamic Azad University of Science and Research. He holds a bachelor's degree in management from Tehran University.

He has 19 years' senior management in the water and wastewater industry. 